\title{
Yerel Değerler Bağlamında Bir Tasarım Ürünü Olarak Turistik Hediyelik Eşya
}

\author{
Souvenir as Design Object in the Context of Local Values \\ Nazlı Gürgan \\ Dr. Öğr. Üyesi, Yaşar Üniversitesi Sanat ve Tasarım Fakültesi Grafik Tasarımı Bölümü \\ email: nazli.gurgan@yasar.edu.tr (DORCID ID: https://orcid.org/0000-0002-5004-8235
}

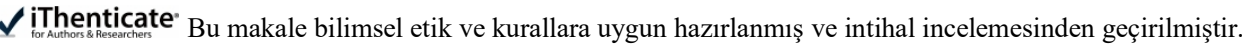

Atıf (APA 6)/To cite this article

Gürgan, N. (2020). Yerel değerler bağlamında bir tasarım ürünü olarak turistik hediyelik eşya. Atatürk Üniversitesi Güzel Sanatlar Enstitüsü Dergisi, 26(44), 287-293. doi: https://doi.org/10.35247/ataunigsed.670804

Makale Gönderim Tarihi/Received: 06/01/2020

Makale Kabul Tarihi/Accepted: 11/03/2020

Makale Yayın Tarihi/Published: 19/03/2020

Review Article / Derleme Makalesi

$\ddot{\mathbf{O} z}$

Turistik hediyelik eşyalar, ticari olarak üretilen ve satın alınan, satın alan kişiye deneyimini hatırlatmak üzere evrensel olarak turizm ile ilişkili ürünlerdir. Turist için bu ürünler hafiza taşıyıcı olmanın ötesinde, kişinin zevklerinin göstergesi olmaktadır. Bu sebeple özgünlük arayışı vazgeçilmezdir, ancak ürünler turistik satışa yönelik kurgulanarak tek tipleşmiştir. Söz konusu ürünler, algılanan özgünlükleri bağlamında nasıl değer kazanabilecektir? Turizm kentlerindeki hediyelik eşya örneklerinin incelenmesi sonucu; yerel ürün/üretim yöntemlerinin sahiplenilmesi dolayısıyla yerel mirasın korunması, yerel zanaatkar-tasarımcı iş birliğinin güçlendirilerek yerelde istihdamları, böylece yaratıcı girișimciliğin tesvik edilmesi ile yaratıcı ekonominin beslenmesinin gelişmeyi sürdürülebilir kılacağı öngörülmektedir.

Anahtar kelimeler: Hediyelik Eşya, Yerel Ürün, Tasarım, Özgünlük, Turizm

\begin{abstract}
Souvenirs are universally associated with tourism as a commercially produced and purchased object to remind the purchaser of the experience. Beyond being a memory holder for tourists, these products signify personal tastes. Therefore, seeking authenticity is essential, yet products made just for touristic sale became all alike. How will these products gain value in context of perceived authenticity? As a result of analyzing souvenir examples in touristic cities; preserving legacy by embracing local product/production methods, generate employment by empowering local craftsmen-designer collaboration to promote creative entrepreneurship and in turn sustainable development of creative economies is estimate.
\end{abstract}

Keywords: Souvenir, Local Product, Design, Authenticity, Tourism

\section{Giriş}

Hediyelik eşyaların satın alımı, geleneksel olarak turistik aktivitelerin başında yer almıştır. Hediye alma-verme her kültürün ritüelleri arasında olmakla birlikte, araştırmaların çoğu turizm alanında hediyelik eşya üretimi ve satışı üzerine gerçekleştirilmiştir, çünkü günümüzde dünya çapında bölge ekonomileri açısından önemli bir katkıya sahiptir (Cohen, 2001, s. 378). Turizm alanındaki çalışmaların ilk örnekleri, el yapımı ürünler, etnik sanatın tüketim ürünü haline gelmesi ve bu şekilde dönüşen yerel zanaatler olmuştur (Graburn, 1976). Akademik düzeyde ilk kapsamlı araştırmanın 1986 yılında Beverly Gordon tarafından gerçekleştirilmesi sonrasında; tüketicisi üzerine (Anderson \& Littrell, 1995), özgünlügüü üzerine (Blundell, 1993; Littrell, Anderson \& Brown, 1993); Asplet \& Cooper, 2000), turist ve mağaza algıları üzerine, satın alma eğilimleri üzerine (Kim \& Littrell, 1999; Yu \& Littrell, 2003) araştırmalar yapılmıştır (Swanson \& Horridge, 2002; Swanson \& Horridge, 2004; Swanson \& Horridge, 2006). Konu estetik, ekonomik, işlevsel ve felsefi açılardan, alışveriş, el sanatları, hediye kültürü, tüketim, maddi kültür ile birlikte incelenmiştir (Swanson \& Timothy, 2012). Hediyelik eşyanın anlam ve etkileri üzerine araştırmalar turizmin yanı sıra, tarih, felsefe, sosyoloji, antropoloji, pazarlama gibi birçok farklı disipline yayılmıştır ancak tasarım alanında henüz konuyla ilgili inceleme yapılmadığı gözlemlenmiştir. Bu sebeple, kentlerin tanıtımlarının bir parçası olan hediyelik eşya tasarımı üzerine, marka ve ürün örnekleri üzerinden tasarım odaklı inceleme yapılmıştır. Bu incelemenin sonucunda, hediyelik eşya ürünlerinin yerel üretici ve tasarımcı iş birliği ile değer kazanması öngörülmektedir.

\section{Yöntem}

Turistik hediyelik eşya anlam, üretim ve satış yöntemleri üzerine gerçekleştirilen literatür taraması sonrasında Avrupa genelinde turizm bölgelerine ait markalar incelenmiştir. Söz konusu markalara ait ürünlerin görsel analizleri tasarım odağında yapılarak yerel değerlerin özgün üretime dönüştürülmesi önerilmiştir.

\section{Turist ve Hediyelik Eşya}

Kent, tarihin hemen her döneminde değișen anlamlara sahip dinamik bir yap1 olmuştur. Medeniyetlerin tanımlanması ile hızla gelişen kentler, 19. yüzyıldan itibaren günümüzdeki şeklini alarak, firsat çeşitliliği 
barındırması sebebiyle cazip hale gelmiştir. Söz konusu tarih aynı zamanda çalışma biçimi ve buna bağlı olarak ücretli tatil kavramını da yaratmıştır. Takip eden süreçte ulaşım olanaklarının gelişmesi, turizmi kentler için vazgeçilmez kılmıştır. Kent, hedef kitlesi olan ziyaretçisine, turiste, yönelik yapılan tanıtım çalışmalarında, logo ve çeşitli tanıtım malzemelerinin yanı sıra, yerel değerlerin de gösterilmek istendiği hediyelik eşya ürünleri önemli bir yere sahiptir. Yerel değerlerin ürüne dönüşmesi, salt pazarlama değil aynı zamanda koruma amacı da taşımaktadır.

Turistik hediyelik eşyalar, ticari olarak üretilen ve satın alınan, satın alan kişiye deneyimini hatırlatmak üzere evrensel olarak turizm ile ilişkili ürünlerdir (Swanson \& Horridge, 2006, s. 671). Neredeyse her seferinde, seyahat eden kişi, deneyimini korumak ve yüceltmek üzere yanında gittiği yerlerden aldıkları ile evine dönmektedir. Her yıl milyarlarca dolar değerinde üretim ve satışı olan hediyelik eşyaların alımı, turizm bölgelerinin vazgeçilmez aktiviteleri arasında yer almaktadır. Tatildeki birçok kişi için alışveriş vazgeçilmezdir ve turistlerin aldıkları ürünlerin birçoğu hediyelik eşya (souvenir) kategorisine girmektedir. Anı göstereni olarak hediyelik eşya, hatırlanmak istenen yer ve zamana geri dönüşü sağlama amaciyla, evlerde aile üyeleri ve misafirlerin de görebileceği şekilde konumlandırılmaktadır. İnsanların hayatında bu denli yer kaplayan turistik hediyelik eşyaların üretimi, yerel zanaatlerden ucuz seri üretime dönüşmekte ve bu durum, yerel üretici, ürün kalitesi, alışveriş deneyimi gibi değişkenler açısından sıkıntı yaratmaktadır.

Turist kavramını tanımlamak üzere 19. yüzyıl başında Samuel Pegge, "Bugünlerde gezgin, tour-ist olarak adlandırılıyor. "Tour" kelime anlamı başladığ farklı olarak turist her zaman eve dönme amacını taşır" demiştir. Turistin keyif ya da kültür içeren ve eve dönüşle sonuçlanan gezisi, diğer durumlara göre daha lüks motivasyon olarak görülmektedir. 1810'lardan itibaren yaygın olarak kullanılmaya başlanan turizm kelimesi, sadece dairesel hareketi değil zaman içerisinde dev bir sektörü tanımlayacaktır. Turizm her ne kadar modern dünyanın bir parçası olsa da, Tourism in History: From Imperial Rome to the Present adlı kitabın yazarı Maxine Feifer'a göre, Batı'da Antik Roma döneminden itibaren var olmuştur (Lasusa, 2007, s. 272). Turistin orada bulunmasının kanıtı, kişisel arşivinin, tarihinin bir parçası olarak topladığı nesneler, hediyelik eşyalar da aynı sürecin parçası olmuştur.

Hediyelik eşya, uzun zamandır seyahatlerin parçasıdır. Antik Mısır, Roma'dan kaşif-gezginler dönüşlerinde hatıra nesneleri getirmişler, keşifler ve Orta Çağ dönemlerinde, gezginlerin limanlarına bir takım el sanatları ürünleri ile dönmeleri şaşırtıcı olmamaktaydı. Bazı araştırmacılar ise, günümüz hediyelik eşyanın kaynağını Hristiyan hac yollarında göstermiştir (Swanson \& Timothy, 2012, s. 489). Daha önce bahsedildiği gibi, çağdaş turizmin gelişimi 19. yüzyılda Sanayi Devrimi ile paralel ilerleyerek, günümüz çalışma koşullarının oluşması, ücretli izin durumunun ortaya çıkışı ve kentlerde çalışanların geldikleri bölgelere ya da tatil beldelerine gitmesi ulaşım teknolojilerinin de gelişmesiyle toplumsal yaşamda yerini almıştır. İkinci Dünya Savaşı sonrası ise, oluşan yeni ekonomi ile güncel konumuna ulaşmıştır. Turistik hediyelik eşyalar, zaman ve parasını paket programlara ayırarak yeni bir deneyim satın alan turist için, bu durumun kanıtı haline gelmiştir.

İngilizce ve Fransızca'da kullanılan souvenir kelimesinin kökeni Fransızca'ya dayanmakta ve fiil olarak hatırlama eylemini tanımlamaktadır. İngilizce'de ise, bir şeyin hatırlandığı nesneye verilen isimdir. Türkçe'de kelimenin doğrudan çevirisi anı nesnesi olmakla birlikte, hediyelik eșya terimi yaygın kullanılarak hediye kelimesi ile çağrışımları da bu yönde olmaktadır. Hediye, Arapça'da "yol göstermek, doğru yola itmek" anlamını taşıyan "hidayet" kelimesinden türemiş, "sevgi ve saygı ifadesi olarak karşılıksız verilen şey, armağan" olarak yerleşmiştir. Kelimenin Türkçe tanımı ise; "birini sevindirmek, mutlu etmek için verilen şey, ödül, bağış, ihsandır" (Coşar, 2008, s. 35). Turistik hediyelik eşyanın hediye olarak verilmesi ise konuyu, Marcel Mauss (Mauss, 1966) ile başlayıp günümüze kadar birçok araştırmacı tarafından geliştirilen hediye vermenin kuramına götürmekle birlikte bu yazıda bahsi geçen turistik hediyelik eşya, turistlere yönelik ziyaret edilen bölgeyi hatırlatmak (tanıtmak) üzere satılan ya da o amaçla satın alınan yerel ürünler olmaktadır.

Hediyelik eşya edinmek üzere yapılan alışveriş, seyahat esnasında en yaygın aktivitelerden bir tanesidir. Tatildeyken alışveriş yapan kişi, daha serbest ve özellikle ihtiyacı olmayan ürünleri almak gibi, gündelik hayatındaki satın alma davranışından farklılık göstermektedir. Bu davranışlar, evdeki bağlardan kopma ve uzakta olmanın getirdiği artan özgürlük hissini temsil etmektedir. Ayrıca, tanıdık olmayan bir ortama uyum sağlamak için bir aracı olmaktadır. Bir diğer görüş ise, başta kendi hayatındaki özgünlüğü kaybeden kişinin başka kültürlerde bu arayışa girmesi olmaktadır. Turistin kendi hayatına bakışı sebebiyle, başka bir kültürün ürününü edinmek onu dünya hakkında daha bilgili hale getirmektedir. Bu noktada yerel olarak üretimi yapılan nesneler önem kazansa da ortaya çıkan sorun, bu özgünlüğün aslında yine kendisine özel olarak kurgulanmış şekilde sunulmasıdır (Lasusa, 2007, s. 283).

İnsanlar daha sık seyahat ettikçe, satın aldıkları da o oranda azalmaktadır. Kişi için nesneler hafıza taşıyıcı, hatırlatıcı olmanın ötesinde, özellikle hediye alınması ile, kişinin bireyselliği, yaratıcılığı ve estetik zevklerinin de göstergesi haline gelmektedir. Bu açıdan, kişilerin hediyelik eşya olarak yerel ürünleri tercih etmesinin sebepleri araştırıldığında; ürün özgünlüğü/yerelliği, kültür ve tarih birlikteliği, kalite, üretici ile bağlantı, işlevi ve garantisi 
öne çıkmaktadır. Ürünün bir diğer rolü, seyahatin kanıtı olmasıdır. Turistik hediyelik eşya, seyahat eden kişinin ev ya da işyerinde onun yerine sorumlulukları üstlenen kişiye hediye verme amacı da taşımaktadır. Ayrıca, bazı kültürlerde hediye verme, seyahatten dönmenin beklenen bir parçası olmaktadır. Son olarak, bu ürünler ziyaretin yerine geçme rolünü de üstlenebilmektedir. Ziyaret edilen mekanda kısa süre kalan turist, zamanının çoğunu mağazada geçirebilmekte, böylece mağazadaki ürünler de ziyaretin temsilcisi haline gelmektedir.

Hediyelik eşyalar; üretilen, satılan ve tüketilen fiziksel ürünler olarak, yerel zanaatten fabrikasyona kadar çok kapsamlı bir kategoridir. Bu açıdan, üreticisi ile birlikte tanımlanmaktadır. Satın alınan hediyelik eşyalar arasında yerel zanaatlere ilgi, özgün ürün arayışında önemli bir yere sahiptir ancak sadece turiste yönelik ürün kurgusu yerel üretimin doğal gelişimini olumsuz etkilemektedir. Bu şekilde önce ticarileştirme ile anlamını kaybeden yerel ürün ve zanaat, süreç içerisinde üreticisi ile ürünün bağının da kopmasına sebep olmuştur (Swanson \& Timothy, 2012, s. 489-499). Böylece turistik hediyelik eşyanın zihinlerde canlanan anlamı, kalitesiz seri üretim ya da kaliteli, pahalı ama garantisi olmayan ürün haline gelmiştir. Benzer algının tasarımcılarda da olması sebebiyle yakın zamana kadar çalışma alanları içerisinde yerini almamıştır.

\section{Hediyelik Eşya Tasarımı}

Tarihsel geçmişi de düşünüldüğünde, seyahat edenin özgün ürünler bulma amacıyla yerel zanaat örneklerini satın alması sebebiyle, ilk akademik araştırmalar turizm çalışmalarında ve daha çok etnik sanat üretiminin turistlere yönelik sürdürülmesi üzerine olmuştur. Beverly Gordon (1986) ile başlayan yönelim devam eden süreçte, tarih, felsefe, sosyoloji, antropoloji, pazarlama gibi birçok disipline yayılmıştır. Uygulama alanında ise ancak son dönemde bazı yerel yönetimler ve tasarımcıların ilgisini çekmeye başlamıştır. Tasarımı oluşturan ürün özellikleri, satın alma kararını doğrudan etkilediği için söz konusu özelliklerin oluşturulmasına yönelik tüketici yaklaşımları üzerine araştırmalar yapılmıştır. İlk olarak, John Crompton (1979) tarafından seyahat motivasyonları belirlenmiştir. Gündelik hayattan kaçış, keşif, rahatlama, prestij, ilişkileri geliştirme, sosyal etkileşimin kolaylaştırılması, eğitim ve yenilik olarak belirlenen bu etkenler, turistleri sınıflandırıp alt kategorilere ayırarak pazarlama amacı ile kullanılmaya başlanmıştır (Swanson \& Horridge, 2006, s. 672). Bu sınıflandırma, odaklı pazarlama stratejileri ve ürün geliştirilmesi için önemli olması sebebiyle Crompton'dan sonra da birçok araştırma konusunun içeriği olmuştur. Bu araştırmalar tasarımcılar için yön bilgi olmaktadır.

Hediyelik eşya ürünleri, tıpkı diğer tüketici ürünleri gibi ürün ömrü sürecine sahiptir ancak gündelik tüketim ürünlerinden farklı olarak, tek seferlik alınması, iade, değiştirme imkanlarının neredeyse olmadığ gibi daha uzun süreli kullanım ya da saklama amacı ile satın alınmaktadır. Bunun gerçekleşmemesi durumunda ise, sadece satın alınan ürüne, üreticiye karşı değil ziyaret edilen bölgeye karşı olumsuz görüşler ile satın alma deneyimi sonuçlanabilmektedir. Ürün ne olursa olsun, satın alma tercihini etkileyen en önemli özellikler arasında; kolay taşınabilirlik, fiyat ve işlevsellik gösterilmektedir.

Ürün çeşitliliği konusunda, Gordon (1986) hediyelik eşya tipolojisini oluşturmuştur. Bu sınıflandırma; pictorial image (kartpostal gibi), piece-of-the rock (doğadan alınan hatıra), symbolic short hand (minyatür Eiffel Kulesi gibi), markers (üzerinde yer ismi olan gündelik ürünler) ve o bölgeye özgü malzemelerle üretilen yiyecek v.b yerel ürünlerden oluşmaktadır (Gordon, 1986, s. 141-142). Bu temel ürün tipleri süreç içinde değişiklik göstermemekle birlikte, tasarım değeri kazanması son dönemde gündeme gelmiştir. Bu açıdan, seyahat dönüşü evde yerini alan herhangi bir ürün tasarım ve algılanan özgünlüğü bağlamında nasıl değer kazanabilmektedir? Yerel zanaatin dikkat çekici hale getirilmesi ya da sıradan gündelik kullanım nesnelerinin turistik hediyelik eşya haline getirilmesinin başarılı örnekleri arkasında, tüm bu kategorilerin farkında olmanın yanı sıra tasarım farkındalığı yaratılması da önemli olmaktadır. Hediyelik ürünler, turizm bölgelerinde yerelde üretilip pazaryerlerinde ya da küçük dükkanlara yığılmış çoğu ithal seri üretim ve üzerlerine sadece o yerin isminin basılmasıyla satılan ürünlerdir. Bu durumda, belli bir tanıtım stratejisine dayanmayan ve yerel üretimi desteklemeyen süreci ortaya çıkmaktadır.

Yaşadığı yerden farklı bir coğrafyaya giden turistin özgünlük arayışı, yerel zanaatlere ilgiyi öne çıkarsa da tüm pazarda olduğu gibi zanaatkarı yaşatamamıştır. 20. yüzyıl sonu itibarıyla tüm dünyada küreselleşme, kentleri tek tipleşme sorunu ile baş başa bırakmıştır. Aynı mağazalar, aynı ürünler, benzer yaklaşımlar ile birçok yer kendi geçmişine, yerel kültürüne dayanan özgünlüğünü yitirmiştir. Bu bağlamda, bir zamanlar maddi kültürün tamamını temsil eden zanaat üretimi, yerini seri üretime bıraksa da 21. yüzyılda tüketim kültürüne karşı yeni bir yaklaşımla yeniden pazara girmiştir. Önceki yüzyılın üretim yöntemlerindeki değişimler, sanat-zanaat-tasarım ilişkileri ve tanımlarında zanaatin geçmişin kaybolan değerleri arasında olmasına rağmen, son dönemde geleneksel üretim yöntemleri ile yeni teknolojilerin bir araya gelerek yaratıcı alanlara yeni çalışma imkanları sunması sonucunda, yeni nesil bağımsız tasarımcılar günümüz zanaat öncüleri haline gelmiştir. "Designer-Maker" olarak da adlandırılan günümüz tasarımcısı, üretimin tüm süreçlerinde aktif görev alarak ürünleri fabrikasyon, tek tip olmaktan çıkarmaktadır. Geçmiş ve geleceğin teknolojileri, el yapımı ve dijital, bir araya getirilerek, heyecan verici günümüz uygulamalarında yeni bir "hibrid" estetik ortaya çıkarılmıştır (Chen, 2011, s. 1). Söz konusu tasarımcılar, üretimleri ile bulundukları kentin tanıtımına yönelik hediyelik eşya olabilecek ürünleri oluşturmakta ve bu konuya dikkat çekilmektedir. 


\section{Turistik Hediyelik Eşya Örnek İncelemesi}

Günümüz satın alma deneyimi geçmişe oranla, başta internet olmak üzere, birçok farklı noktada gerçekleşmektedir. Seyahat esnasında ise, mağazalar önemini yitirmemiştir. Buna rağmen bir mağazanın diğerinden ayırt edilemeyecek şekilde benzer ürünlerin satışa sunulması, sıkıcı bir alışveriş deneyimine sebep olduğu gibi, kentleri de birbirine benzer hale getirmektedir. Son dönem tüketim eğilimlerinde marka hikayesinin önem kazanması, seri üretimin tek tip olmasına karşı, kişisellik, özgünlük arayışındaki tüketicinin satın aldığı ürünün kaynağı bilme isteği ile bağlantılıdır. Hediyelik eşyaların farklılık yaratması, turizm deneyimini olumlu etkileyeceği gibi, halkını ve onun parçası tasarımcısını destekleyen üretim modelleri oluşturulmasına da imkan verebilecektir.

Hediyelik eşya tasarımında, ortak etkenin çalıșılan yer olduğu ve tasarımcısının üretimini yerel değer olarak sunan yenilikçi bir iş modeli örneği, "Londra, daha iyisini yapabiliriz" sloganı ile, We Built This City mağazasıdır. İlk olarak 2014 yılında, Londra'nın turistik noktalarından Carnaby'de pop-up mağaza olarak satışa başlayıp, talebin çok olması sonucu mağaza kalıcı hale getirilmiştir. 250'den fazla yerel tasarımcının ürünleri satılmakta ve mağaza tasarımcıyı görünür kılarak hedef kitlesine ulaşmak için platform sağlamaktadır. Aynı zamanda ürünü satılan tasarımcıların atölye çalışmaları ve performanslar düzenlemesi sağlanarak yerel bir komünite de oluşturulmakta, böylece bu alanlarda yeni üreticilerin oluşması da sağlanmaktadır. Bu şekilde WBTC mağazası, Londra'daki birbirine benzer birçok hediyelik eşya mağazasından farklılaşarak hem turistlere yenilikçi ürünler sunarken yerel tasarımcıyı desteklemekte ve işlerini sürdürülebilir kılmakta hem de hedef kitlesini sadece turistler değil, yerel halk olarak da belirleyebilmektedir. Yeni bir satış modeli olarak ortaya çıkan mağaza, aynı zamanda internet üzerinden de satış yaparak hedef kitlelerine tek seferlik satışın ötesinde, hem mağazaya hem de tasarımc1 markalarına karşı marka sadakati yaratmayı da amaçlamaktadır (Görsel 1).

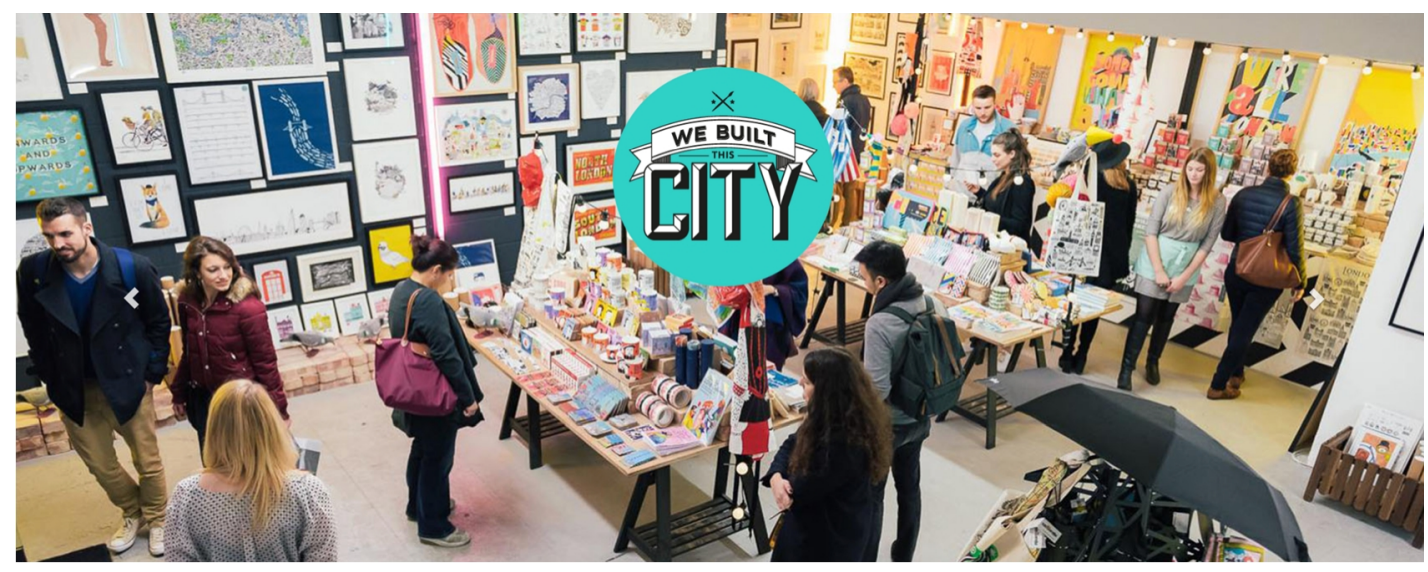

Görsel 1. We Built This City mağaza genel görünüm, Londra.

Turizmin önemli noktalarından biri olan Yunanistan, son dönemde yerel markaları ile öne çıkmıştır ve bu durum turistik hediyelik eşya alanında da gözlemlenebilmektedir. Üretimi canlandırıp yerel kültürün korunmasına imkan verildiği bir özgünlüğe ulaşma örnekleri arasında When in Greece markası öne çıkmaktadır. Turistik hediyelik eşya markası olarak 2014 yılında kurulan marka, Yunan tasarımcılar tarafından yerel malzeme kullanılarak kaliteyi ön plana çıkarma ve yerel üreticiyi destekleme amacı taşımaktadır. Ürünlerde malzemenin kaynağı vurgulanırken, birçok ürünün dikkat çekiciliği illüstrasyon ve tipografisi ile grafik tasarım uygulamalarına dayanmaktadır (Görsel 2).
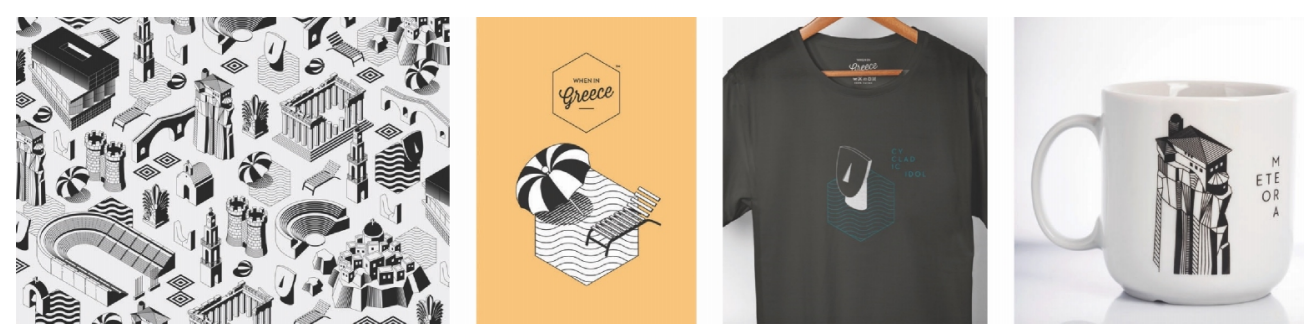

Görsel 2. When in Greece, Yunanistan. İllüstrasyon; kartpostal, t-shirt ve bardak uygulamaları örnekleri. 
Yunanistan'da farklı üretim ve satış modellerine örnek olabilecek birçok marka olmakla birlikte, yerel tanıtımı aşarak ülke dışında mağaza açması ile önemli örnekler arasında Sakız Adası'nda yer alan Mastiha Shop bulunmaktadır. Marka, 2002 yılında Sakız Yetiştiricileri Birliği tarafından, sakızın üretim, tanıtım ve satışını geliştirmek üzere kurulmuştur. Bu kapsamda ana ürünler sakız içermekle birlikte, farklı içeriklerde birçok ürün de mevcuttur. Mağazanın konsepti, yerel ürünlerin dikkat çekici ambalaj tasarımları ile sergilenerek satışa sunulması üzerine kurulmuştur. İçi boş satılan kutular, satın alınan ürünlerin istenildiği gibi yerleştirmesiyle özelleştirilerek, turistlerin kişiye özel ürün oluşturmalarına imkan vermektedir. Marka hikayesi doğrudan tasarımcı üzerinden değil, yerel ürün üzerinden tasarım aracılığıyla aktarılmaktadır (Görsel 3).
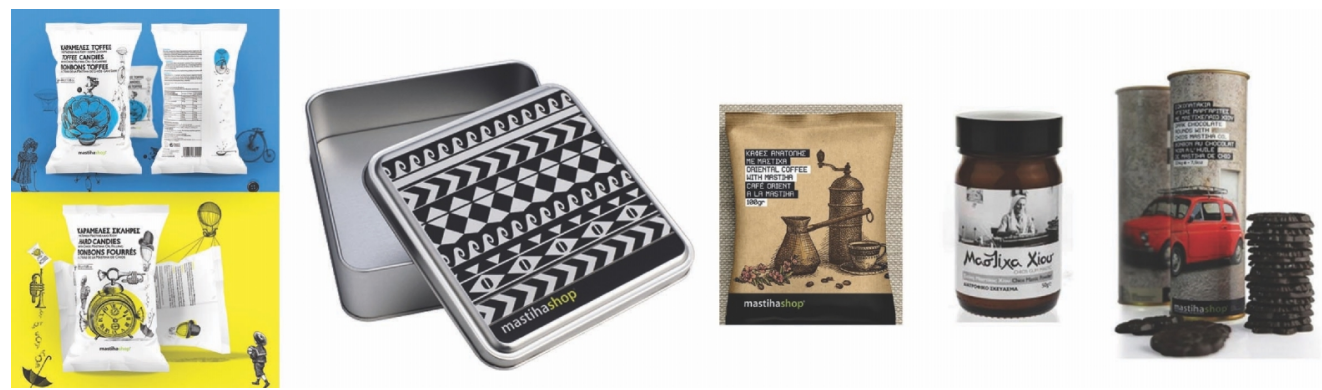

Görsel 3. Mastiha Shop, Sakız Adası Yunanistan.

Akdeniz kıyıları boyunca, bölge halklarının gündelik hayatlarının parçası olan zeytin, zeytinyağı ve ürünleri, günümüzde yerel ürün kategorilerinin de başında yer almaktadır. Bu bölgelerin küçük yerleşim birimlerinde çoğunlukla butik satış birimlerinde satılan ürünler olduğu gibi daha tanınan markaların mağazaları da yer almaktadır. Örneğin; Marius Fabre tarafından 1900 yılında, Marsilya yakınında bulunan Salon-de-Provence'ta kurulan sabun üretim tesisi, günümüzde aile işletmesi olarak üretimini sürdürmektedir. Ailenin yanı sıra, yerel halk da birkaç kuşak boyunca tesiste çalıșarak, yerel miras olan Marsilya sabunu üretiminin bir parçası olmuştur. Marka, geleneksel üretimin sürdürülmesi ile Yaşayan Miras (Enterprise du Patrimoine Vivant) belgesine değer görüldüğü gibi, Marsilya Sabunu Üreticileri Birliği kurucusu olarak da bölgede önemli bir yere sahiptir. Günümüzde, tüketicinin doğal ürün arayışı sebebiyle tercih ettiği zeytinyağlı sabun üretiminin yerel olarak sürdürülmesi ile yerel değer olarak satışa sunulması, herhangi bir seri üretim turistik hediyeden çok daha dikkat çekici olmaktadır. Firmanın arşivindeki ürün, ambalaj v.b örnekleri sergilediği sabun müzesi de bu açıdan önemli bir duraktır (Görsel 4).
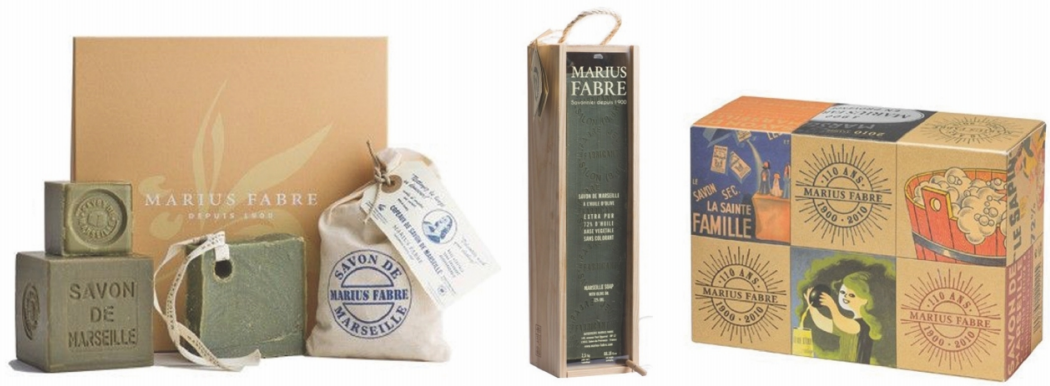

Görsel 4. Marius Fabre, Fransa. Marsilya sabunu hediyelik ürün örnekleri.

Yerel ürün, malzeme, geleneksel üretim yöntemleri turistik hediyelik eşyanın kritik başlıklarıdır. Bu parçaların çağdaş tasarımcı ile bir araya gelerek mağaza konsepti, ürün, ambalaj tasarımı geliştirilmesiyle değer kazanması odak noktalardır. Ancak tüm bu başlıkların neredeyse hiçbirini içermeden, yalnızca yerel yaşam tarzının görsel dil bütünlüğü ile aktarılması, Derriére La Porte (DLP) markası tarafından gerçekleştirilmiştir. DLP, hikayesini gündelik hayatın renkleri ve neşesine dayandırdığını belirterek, bünyesindeki tasarımcılar ile işlevsel ve dekoratif birçok ürünü satışa sunmaktadır. Söz konusu gündelik hayat, Paris'e ait, "Parizyen" havayı görsel dilinde yansıtmaktadır. Güncel grafik tasarım trendleri olan illüstratif yaklaşım ve el yazısı tipografik stil duygusal etki yaratma amacıyla kullanılmıştır. Buradaki "Made in France" ürünün kendisi değil Fransız yaşam biçimi atmosferinin görsel tasarımıdır (Görsel 5). DLP, ürünlerini kendi mağazasında sattığı gibi, internet üzerinden ve 
kent çapında hediyelik eşya mağazalarında da satışa sunmaktadır. Böylece, kentin hediyelik eşya mağazaları da ürün çeşitliliği açısından gelişim göstermiştir.
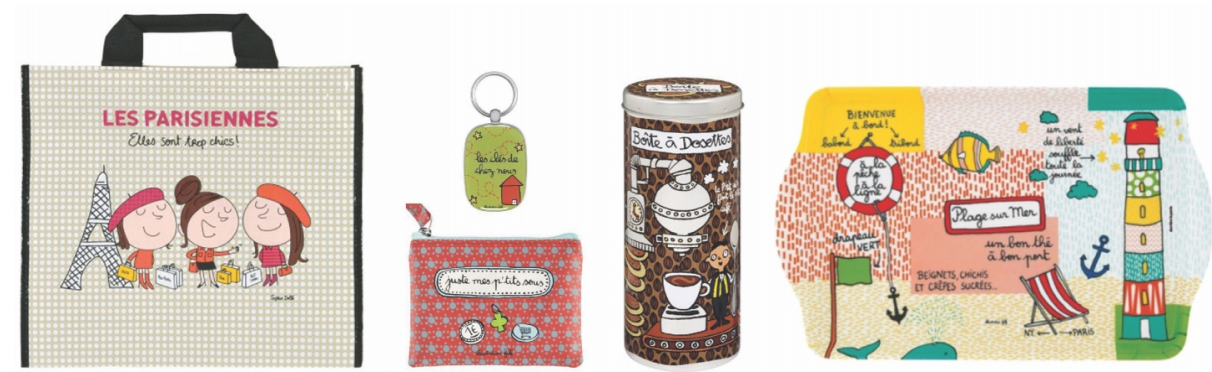

Görsel 5. DLP, farklı koleksiyonlarından alışveriş çantası, anahtarlık, küçük çanta, teneke kahve kutusu, tepsi.

Tasarım, üretim ve satışları açısından incelenen hediyelik eşya örnekleri; turistlere yönelik üretilen ürünlerin tek tipleşmesine, yerel üretime yabancılaşmasına karşı, her açıdan yerelliği desteklemeleri ile çözüm önerilerini barındırmaktadır. Turizm bölgesine özgü hammadde, üretici, tasarımcı üretimi örneklerin odak noktasındadır. Hediyelik eşyalar, hem ürün tasarımı hem grafik tasarımın uygun kullanımının sunum ile bütünleşmesiyle başarılı örnekler haline gelmektedir. Sahip olunan yerel değerlerden geri kazanım ancak farklılaşma ile mümkün olmaktadır. Böylece, sadece turiste yönelik değil, gerek kendi kullanımı gerek hediye olarak satın alımı ile yerel halka da yönelik olabilmektedir.

\section{Sonuc}

Dünyanın modernleşme ve mobilizasyonu, özellikle Batı toplumlarını gelenek ve köklerinden uzaklaşmaya, bağ kuramamaya ve bu sebeple anlam arayışına itmiştir. Toplumun bir bireyi olan turist, kendi kişisel tarihi, dolayısıyla anlam yapılandırmasına çalışmaktadır. Turizmin popüler hale gelmesi de bu arayışın bir parçası olarak algılanmasına bağlanabilmektedir. Bütün yıl çalışan ve ücretli izin döneminde özgürleşen turiste yönelik oluşturulan turizm bölgelerinin temel problemi, bu yabancılaşmayı desteklemesidir (Lasusa, 2007). Bahsi geçen süreç ve anlam arayışı, Avrupa ile aynı zamanda olmasa bile Türkiye'de de aynı sonuçları beraberinde getirmiştir. İçinde bulunduğumuz coğrafya, bölgeleri, kültür birikimi, yerel ürün, üretim yöntemleri ile önemli bir potansiyeli barındırmaktadır. Bu kaynakların bir araya getirilip desteklenmesi sürdürülebilirlikleri açısından gereklidir. Yerel üretim/zanaat ve yerel tasarımcı ile iş birliği projelerinin oluşturulması ve devamlılığının sağlanması yerel değerleri koruma açısından fırsatları barındırmaktadır. Örneğin; İstanbul Kalkınma Ajansı tarafından 2015 yılında Yaratıcı Endüstrilerin Geliştirilmesi Mali Destek Programı ${ }^{1}$ kapsamında, Hediyem Istanbul ${ }^{2}$, Zanaattan Tasarıma ${ }^{3}$ gibi bu anlamda etkin projeler hayata geçirilmiştir. Bu projelerde amaç, kısa vadede kazanç sağlamak değil uzun vadede değer yaratmaktır. Böylece, yerel tasarımcının üretiminin, yerel hammadde kullanımıyla üreticinin ve geleneksel üretimin desteklenmesi ile yerel değerlerin sürdürülebilir kılınması, toplumun bireylerindeki yabancılaşmayı önleyerek bağlarını güçlendirmeyi sağlayacaktır. Buna bağlı olarak; turistik hediyelik eşya üretiminin, yerel olarak tahmin edilenden çok daha geniş olumlu yan etkileri bulunmaktadır. Yerel üreticinin desteklenmesi ile yerel değer, miras olan ürünlerin korunması, tasarımcı iş birliği ile söz konusu ürünlerin dikkat çekici tüketici ürünleri haline dönüşmesi, yerel tasarımcının şehir/yurtdışına gitmesi yerine yerelde istihdamı ile yenilikçi küçük işletmelerin sürdürülebilir kılınması, böylece yaratıcı ekonominin dolayısıyla bölgenin ve ülke ekonomisinin güçlenmesi söz konusu olmaktadır. Bu projelerin yanı sıra, son dönemde birçok satış noktasına ulaşabilecek ürünlere yönelik tasarım yarışmaları da düzenlenmektedir. Örneğin, kadın tasarımcıların görünürlüğünü arttırmak üzere 2019 yılından itibaren, Türkiye çapında müze ve ören yerlerindeki mağazaları işleten Anadolu Kültürel Girişimcilik tarafından Anadolu'nun Kadın Gücü adlı yarışma düzenlenmekte ve yerel değerlere dikkat çekilmektedir. ${ }^{4}$

Sonuç olarak, hediyelik eşya ürünleri seyahat deneyiminin her aşamasına işlemiş ve birçok forma sahip parçası olmuştur. Mekanları anlatan, kimlik oluşturan, iş sağlayan, gezi anısı haline gelen bu parçalar binlerce yıldır var olmuş ve insanlar seyahat etmeyi sürdürdükçe de var olacaktır. Yaygın uygulamalarında, olumsuz çağrışıma sahip bu ürünler geçmişten gelen birikimin çağdaş tasarım uygulamaları ile bir araya getirilmesiyle yeni bir kimliğe kavuşabilecektir. Bu kimlik, çağdaş tasarım uygulamalarını sürece dahil ederek farkındalık yaratılması ile benimsenebilecektir. Bu şekilde yerel değerler özgün üretime dönüşebilecek ve yerel halk gururla bu üretimin ya da sunumunun bir parçası olacaktır.

\footnotetext{
${ }^{1}$ Detaylı bilgi için Bkz. http://www.istka.org.tr/media/1097/yaratıcı-endüstrilerin-geliştirilmesi-mali-destek-programı.pdf

${ }^{2}$ Detaylı bilgi için Bkz. https://hediyemistanbul.com/Pages/Hakkimizda

${ }^{3}$ Detaylı bilgi için Bkz. http://www.istanbulmodern.org/tr/basin/basin-bultenleri/zanaattan-tasarima_1874.html

${ }^{4}$ Anadolu Kültürel Girişmcilik tarafından düzenlenen yarışma ile ilgili ayrıntılı bilgi için; http://anadolununkadingucu.com
} 


\section{Kaynakça}

Anderson, L. F. \& Littrell M. A. (1995). Souvenir-purchase behavior of women tourists. Annals of Tourism Research, 22, 328-348. Erişim adresi:https://www.cabdirect.org/cabdirect/abstract/19961801296

Asplet, M. \& Cooper M. (2000). Cultural designs in New Zealand souvenir clothing: The question of authenticity. Tourism Management, 21, 307-312. doi: https://doi.org/10.1016/S0261-5177(99)00061-8

Blundell, V. (1993). Aboriginal empowerment and souvenir trade in Canada. Annals of Tourism Research, 20, 6487. doi: https://doi.org/10.1016/0160-7383(93)90112-G

Chen Design Associates. (2011). Fingerprint No.2 The evolution of handmade elements in graphic design. Ohio: HOW Books.

Cohen, J. H. (2001). Textile, tourism and community development. Annals of Tourism Research, 28, 378-398. doi: https://doi.org/10.1016/S0160-7383(00)00060-8

Coşar, M. (2008). Türk kültüründe hediyenin algılanışı. İ̈̈ Türk Dili ve Edebiyatı Dergisi, 38, 33-48.

Gordon, B. (1986). The souvenir: Messenger of the extraordinary. Journal of Popular Culture, 20, 135-146. doi: https://doi.org/10.1111/j.0022-3840.1986.2003_135.x

Graburn, N.H. (1976). Ethnic tourist arts: Cultural expressions from the fourth world. Berkeley: University of California Press

Kim S., \& Littrell M. A. (1999). Predicting souvenir purchase intentions. Journal of Travel Research, 38, $153-$ 162. doi: https://doi.org/10.1177/004728759903800208

Lasusa, D. M. (2007). Eiffel Tower key chains and other pieces of reality: The philosophy of souvenirs. The Philosophical Forum 38, 271-287. doi: https://doi.org/10.1111/j.1467-9191.2007.00267.x

Littrell, M. A., Anderson L. F., \& Brown P. J. (1993). What makes a craft souvenir authentic?. Annals of Tourism Research, 20, 197-215. doi: https://doi.org/10.1016/0160-7383(93)90118-M

Mauss, M. (1966). The Gift: Forms and Functions of Exchange in Archaic Societies. ( I. Cunnison, Çev.). London: Cohen\&West.

Swanson, K. K., \& Horridge P. E. (2002). Tourists' souvenir purchase behavior and retailers' awareness of tourists' purchase behavior in the southwest. Clothing and Textiles Research Journal, 20(2), 62-76. doi: https://doi. org/10.1177/0887302X0202000202

Swanson, K. K., \& Horridge P. E. (2004). A structural model for souvenir consumption, travel activities and tourist demographics. Journal of Travel Research, 42, 372-380. doi: https://doi.org/10.1177/0047287504263031

Swanson, K. K., \& Horridge, P.E. (2006). Travel motivations as souvenir purchase indicators.Tourism Management, 27, 671-683. doi: https://doi.org/10.1016/j.tourman.2005.03.001

Swanson, K. K., \& Timothy D.J. (2012). Souvenirs: Icons of meaning, commercialization and commoditization. Tourism Management, 33, 489-499. doi: https://doi.org/10.1016/j.tourman.2011.10.007

Yu, H., \& Littrell M. A (2003). Product and process orientations to tourism shopping. Journal of Travel Research, 42, 140-150. doi: https://doi.org/10.1177/0047287503257493

\section{Görsel Kaynakçası}

Görsel 1. We Built This City mağaza genel görünüm, Londra. (2017), [Mağaza]. Erişim Adresi: http://www.webuilt-thiscity.com

Görsel 2. When in Greece, Yunanistan. İllüstrasyon; kartpostal, t-shirt ve bardak uygulamaları örnekleri. (2017), [İllüstrasyon]. Erişim Adresi: https://wheningreece.squarespace.com

Görsel 3. Mastiha Shop, Sakız Adası Yunanistan. (2017), [Ambalaj Tasarımı]. Erişim Adresi: https://www.mastihashop.com

Görsel 4. Marius Fabre, Fransa. Marsilya sabunu hediyelik ürün örnekleri. (2017), [Ambalaj Tasarımı]. Erişim Adresi: http://www.marius-fabre.com

Görsel 5. DLP, farklı koleksiyonlarından alışveriş çantası, anahtarlık, küçük çanta, teneke kahve kutusu, tepsi. (2017), [Ürün]. Erişim Adresi: http://www.derrierelaporte.com/en/kansicht/?PPN=PPN735128383\&PHYSI= PHYS 0435 